\title{
Tekrarlayıcı Seronegatif Pitting Ödemli Simetrik Sinovit Sendromu (RS3PE): Bir Olgu Sunumu
}

\author{
Remitting Seronegative Symmetrical Synovitis with Pitting Edema (RS3PE): \\ A Case Report
}

Ayhan Aşkın, Ümit Seçil Demirdal, Ezgi Coşkun Yenigün*, Korhan Barış Bayram

Atatürk Eğitim ve Araştırma Hastanesi, Fiziksel Tıp ve Rehabilitasyon Kliniği, İmir, Türkiye

*Atatürk Devlet Hastanesi, Nefroloji Kliniği, Balıkesir, Türkiye

\section{Özet}

Tekrarlayıcı seronegatif pitting ödemli simetrik sinovit sendromu (RS3PE) ani başlayan ellerin dorsal yüzünde ödem ile şişlik ve sinovit ile karakterizedir. Serolojik testler negatiftir ve radyolojik eklem tahribatı görülmez. RS3PE sendromunun etyolojisi bilinmemektedir. İdiyopatik olabileceği gibi ayrıca en sık olarak geç başlangıçı romatoid artrit ve polimiyalgia romatika gibi romatolojik hastalıklarla da ilişkili olabilmektedir. Ek olarak RS3PE sendromunun paraneoplastik olarak birçok hematolojik ve solid malignitelerle birlikte olabileceği bildirilmektedir. Bu makalede klinik takibinde akciğer kanseri saptanan RS3PE olgusu sunulmuştur. (Türk Osteoporoz Dergisi 2014;20: 89-91)

Anahtar kelimeler: Pitting ödem, seronegatif, sinovit, malignite

\section{Summary}

Remitting seronegative symmetrical synovitis with pitting edema (RS3PE) syndrome is characterized by sudden onset of edema with swelling on the dorsum of the hands and by synovitis. Serological tests are negative and radiographic joint destruction does not occur. Etiology of RS3PE syndrome is not known. It can occur as an idiopathic phenomenon, but also is in association with rheumatic diseases, most frequently with late-onset rheumatoid arthritis and polymyalgia rheumatica. In addition, several reports have described RS3PE as a paraneoplastic syndrome can occur concomitantly with both hematological and solid malignancies. We aimed to present a RS3PE case in whom lung cancer was detected at clinical follow up. (Turkish Journal of Osteoporosis 2014;20: 89-91)

Key words: Pitting edema, seronegative, synovitis, malignancy

\section{Giriş}

Tekrarlayıcı seronegatif gode bırakan ödemin eşlik ettiği simetrik sinovit sendromu (RS3PE); ani ortaya çıkan, simetrik ve sıklıkla el veya ayak bileği eklemlerini tutan sinovit, el veya ayak dorsal yüzünde ödem, parmaklarda fleksör tendinit ile seyreden iyi seyirli bir sendromdur. illk kez 1985 yilında Mc Carty ve ark. tarafından tanımlanmıştır. Genellikle yaşlı popülasyonu ve erkekleri etkiler. Erkek-kadın oranı 4:1 şeklindedir. Hastalığın etyolojisi tam olarak aydınlatılamamıştır. Laboratuvar olarak romatoid faktör (RF) yokluğu ve direkt radyografilerde artiküler erozyon saptanmaması tipiktir. Kortikosteroid tedavisine iyi yanıt vermesi ve sekelsiz iyileşme göstermesi önemli özelliklerindendir $(1,2)$.

Bu sendromun nadir görülmesi klinisyenler tarafından sıklıkla gözden kaçmasına neden olmaktadır. Bu durum hastaların daha uzun süreli ve gereksiz tedaviler almasına neden olmaktadır.
Klinisyenlerin unutmaması gerekli olan diğer bir önemli nokta RS3PE sendromunun çeşitli hematolojik ve solid malignitelerde paraneoplastik olarak karşımıza çıkabilmesidir. Ferrao ve ark. literatüre sundukları olgularının paraneoplastik RS3PE ile başvurmasının erken tanı açısından büyük bir şans olduğunu vurgulamışlardır. Bu nedenle RS3PE tanısı alan hastaların olası malignensi yönünden araştırılması ya da takip edilmesi gerekmektedir (3-5). Amacımız RS3PE tanısı alan ve klinik takibinde akciğer kanseri tespit edilen bir olguyu tartışmak, konu ile ilgili literatürü gözden geçirmek ve klinisyenlere bu sendromun özelliklerini hatırlatmaktır.

\section{Olgu}

Seksen yaşında erkek hasta polikliniğimize son bir haftadır özellikle her iki el bileği ve el dorsalinde gelişen ağrı ve şişlik şikayeti ile başvurdu. Öyküsünde daha önce çeşitli eklemlerinde gezici 
tarzda ağrılarının olduğu, fakat eklemlerinde şişlik olmadığını ifade ediyordu. El parmaklarında olan sabah tutukluğunun bir saatten fazla sürdüğünü belirtiyordu. Romatolojik sorgusunda ek özellik yoktu. Hastanın özgeçmişinde tip 2 diyabet mellitus, kronik böbrek yetmezliği ve koroner arter hastalığı tanıları mevcuttu. illgili branşlarda düzenli takip ediliyordu. Soygeçmişinde özellik yoktu.

Hastanın sistemik muayenesinde tansiyon arteryel 140/80 mmHg, nabız: 82/dakika, ateş: 36,9 idi. Solunum sisteminde dinlemekle sağda orta zondan itibaren solunum seslerinde azalma vardı. Diğer sistemlerin muayenesi normaldi. Kas iskelet sistemi muayenesinde her iki el dorsalinde gode bırakan ödem, el bileği ve el dorsalinde ısı artışı, metakarpofalangial eklemlerde 30 derece fleksiyon hareket kısıtılığı tespit edildi. Diğer tüm eklemlerde eklem hareket açıklıkları normaldi. Aktif artrit yoktu. Laboratuvar incelemede hemoglobin: 10,2 (11-16) g/dl, trombosit: 420 (100-300) K/uL, lökosit: 6,75 (4-10) K/uL, glukoz: 105 (70-105) mg/dl, üre: $51(8,4-25,7)$ mg/dl, kreatinin: 2,03 $(0,7-1,3) \mathrm{mg} / \mathrm{dl}$, total protein: $6,6(6,4-8,3) \mathrm{g} / \mathrm{dl}$, albumin: $3,7(3,5-5,0) \mathrm{g} / \mathrm{dl}$, ürik asit: $7,5(3,5-7,2) \mathrm{mg} / \mathrm{dl}$, ferritin: 17 (22-322) ng/ml, parathormon: $188(19,8-74,9) \mathrm{pg} / \mathrm{ml}$, sedimantasyon: $53 \mathrm{~mm} / \mathrm{saat}$, romatoid faktör: 3,2 (<20) iu/ $\mathrm{ml}$ (negatif), C-reaktif protein: $7(0,01-0,82) \mathrm{mg} / \mathrm{l}$ (pozitif), tam idrar tetkiki normal olarak saptandı. Çekilen ön-arka el-el bileği grafisinde bilateral proksimal ve distal interfalangial eklem aralıklarında daralma, osteofit formasyonu ve periartiküler osteopeni saptandı. Erozyon tespit edilmedi.

Hastada bu bulgularla RS3PE ön tanısı düşünülerek $10 \mathrm{mg} / \mathrm{gün}$ kortikosteroid başlandı ve anti nükleer antikor (ANA) ile anticyclic citrullinated peptide (anti-CCP) tetkikleri istenerek kontrole çağırıldı. Hastanın iki hafta sonraki kontrolünde şikayetinin azaldığı, el dorsalindeki şişlikte belirgin azalmanın olduğu ve istenen romatolojik tetkiklerin negatif olduğu görüldü. Kortikosteroid dozu iki hafta içinde azaltılarak kesildi. Hastanın takibinde eklem şikayetleri tekrarlamadı. Hastanın yaşı, kliniği, laboratuvar ve direkt grafi özellikleri ve steroide hızlı yanıtı göz önüne alınarak RS3PE tanısından emin olundu ve Paraneoplastik sendrom olasılığı için ileri tetkikler istendi. Takiplerinde abdominal ultrasografisi normal gelen hasta, endoskopi ve kolonoskopi tetkiklerin yapılmasını kabul etmedi. Ancak çekilen toraks bilgisayarlı tomografide sağ akciğer alt lobda yaklaşık $5 \mathrm{~cm}$ çapında düzensiz kenarlı yumuşak doku dansitesi, sol hilus alt lob bronş komşuluğunda yaklaşık $3 \mathrm{~cm}$ çapında düzensiz kenarlı yumuşak doku dansitesi şeklinde malign karakterde olabilecek akciğer tümörü tespit edildi. Sonrasında akciğer kanseri tanısıyla kemoterapi programına alınan hasta vefat etti.

\section{Tartışma}

Tekrarlayıcı seronegatif gode bırakan ödemli simetrik sinovit sendromu ilk defa yaşlı erkekleri etkileyen akut başlangıçlı ve simetrik poliartritin bir alt grubu olarak tanımlanmıştır. Etyopatogenezde, tam olarak aydınlatılamamış olmakla beraber, HLA B7 ve HLA A2 ile ilişkilendirilmiş genetik yatkınlığın,
Parvovirus B 19 infeksiyonlarının, romatolojk ve otoimmün hastalıkların rol oynadığı belirtilmektedir (6). Arima ve ark. yakın zamanda vasküler endotelyal büyüme faktörünün (VEGF) hem sinovite yol açan hipervaskülaritede hem de gode bırakan ödeme yol açan vasküler geçirgenlikte rol oynadığını göstermişlerdir (7). Simetrik artrit ve gode bırakan ödem el-ayak bilekleri olmak üzere distal eklemlerde görülür. Metakarpofalangeal, proksimal interfalangeal ve metatarsofalangeal eklemler de tutulabilir. Sendromun diğer karakteristik özellikleri; RF'nin yokluğu, akut faz reaktanlarında artış, direkt grafilerde erozyon olmaması, düşük doz oral kortikosteroid tedavisine hızlı yanıt ve ilacın kesilmesinden sonra iyi prognozdur $(1,2)$.

Sendromun tanı kriterleri ilk olarak Olive ve ark. tarafından; 50 yaşın üzerinde olmak, her iki el dorsumunda gode bırakan ödem, ani başlangıçlı poliartrit ve RF negatifliği olarak tariflenmiştir (8). Hastamız bu tanı kriterlerini karşılamaktadır. Direkt ön-arka el grafisinin sendromu ile uyumlu olması, steroide hızlı yanıt ve ilacın bırakılmasından sonra şikayetlerde tekrarlamanın görülmemesi tanımızı güçlendirmektedir.

Sendromda her iki el dorsumunda görülen ödem tiroidkaraciğer-böbrek hastalıkları, konjestif kalp yetmezliği, lenfatik obstrüksiyon ve sellülit gibi hastalıklardan ayırıcı tanı gerektirir (9). Özellikle uzun süreli diyaliz hastalarında el-ayaklarda ekstrasellüler sıvı birikimi ve amiloid artropatisi gelişimi ile RS3PE sendromuna benzer klinik ortaya çıkabilir. Ancak amiloid artropatisi progresif ve geri dönüşümsüzdür (10). Hastamızda kronik böbrek yetmezliği nedeniyle izlenmekte olan ancak diyalize gerek görülmemiş bir hastaydı. Ani başlangıçlı simetrik artrit, steroid tedavisine belirgin klinik yanıt daha çok RS3PE lehinde değerlendirildi.

Bu sendromun spesifik bir hastalık, diğer romatolojik hastalıklarla ilişkili bir hastalık veya romatolojik hastalıkların bir başlangıç formu mu olduğu kesinlik kazanmamıştır (11). Aşikar kliniğe karşın ayırıcı tanısının yapılması oldukça zordur (6). Ayırıcı tanıda romatoid artrit (RA), sistemik lupus eritematosus, sistemik skleroz gut, miks bağ dokusu hastalıkları, Çakışma sendromu, pseudogut, spondiloartropatiler, Kompleks bölgesel ağrı sendromu ve Karpal-tarsal tünel sendromu düşünülmelidir (12). Ayırıc tanıda özellikle yaşılarda görülen geç başlangıçı RA ve polimyaljiya romatika (PMR) unutulmamalıdır. RS3PE sendromu; erkek hastalarda daha sık görülmesi, eklem destrüksiyonunun olmaması ve negatif seroloji ile RA'dan ayrımaktadır. Ayrıca düşük doz kortikosteroide dramatik yanıt ve ilaç kesilmesine rağmen uzun süreli remisyon yine RS3PE sendromu lehinedir. Illeri yaşta görülmesi, seronegative, yüksek sedimantasyon ve kortikosteroide dramatik yanıt sendromun PMR ile karışmasına neden olmaktadır. Ancak erkek hastalarda görülmesi ve gode bırakan ödem PMR'de beklenmemektedir (3). Hastamızın erkek olması, öyküsünde romatolojik sorgulamanın negatif olması, aşikar fizik muayene bulguları, laboratuvar bulgularında RF negatifliği ve steroide iyi yanıt vermesi ayırıcı tanıda yardımcı olmaktadır.

RS3PE sendromu malignensilerin bir kas-iskelet sistemi belirtisi, bir Paraneoplastik sendrom olarak karşımız çıkabilir. 
Patogenezde tümör hücrelerinden salınan inflamatuvar sitokinlerin rol oynadığı düşünülmektedir. Paraneoplastik RS3PE sendromunun özelikleri arasında kilo kaybı, ateş, anoreksi gibi sistemik bulgu ve semptomlarla seyretmesi ve kortikosteroidlere zayıf yanıt göstermesi vardır. Malignensi sendromdan önce, eş zamanlı ya da daha sonra gelişebilir. Bu nedenle RS3PE sendromu tanısı alan hastalarda Paraneoplastik sendrom ekarte edilmeli ve hastalar olası malignensi nedeniyle uzun dönem, gerekirse ömür boyu izlenmelidir $(3,13)$. Sendrom; lösemi, lenfoma, multiple miyeloma, prostat, mide, pankreas ve endometrium neoplazmları gibi solid tümörler ve hematolojik kanserlerle ilişkilendirilmiştir. Literatürde akciğer kanseri ile birliktelik gösteren vakalar rapor edilmiştir $(5,11,14,15)$. Bizim olgumuz literatüre ek katkı sağlamaktadır.

Hastamızın yaşı nedeniyle hem RS3PE hem de akciğer kanseri tesadüfî birliktelik göstermiş olabilir. Ayrıca hastamızın polikliniğe başvuru sırasında sistemik şikayetlerinin olmaması ve steroide iyi yanıt vermesi Paraneoplastik sendrom açısından kuşku yaratmaktadır. Ancak olgumuzun özellikleri; Mattace-Raso ve ark.'nın (14) 78 yaşındaki bayan hastada rapor ettikleri şekilde neoplazm düşündürecek belirgin sistemik bulgunun olmaması, aneminin varlığı ve kanserin paraneoplastik RS3PE olasılığı nedeniyle ileri tetkiklerde saptanması açısından oldukça benzerdir.

\section{Sonuç}

RS3PE nadir görülen bir sendromdur ve klinisyenler tarafından sıklıkla gözden kaçırılmaktadır. Yanlış tanı ya da ayırıcı tanının uygun yapılmaması nedeniyle hastalar daha uzun süreli ve daha yoğun tedavilere maruz kalmaktadır. Nadir görülmesine rağmen kolay tedavi edilebilir bir hastalık olması ve iyi prognoz nedeniyle unutulmamalıdır. Diğer önemli bir nokta ise RS3PE sendromunun malignensiler ile birliktelik gösterme potansiyelidir. Özellikle sistemik semptom ve bulgular ile steroid tedavisine zayıf yanıt söz konusu ise klinisyen neoplazm olasılığını unutmamalı ve hastaları uzun dönem takip etmelidir.

\section{Kaynaklar}

1. McCarty DJ, O'Duffy JD, Pearson L, Hunter JB. Remitting seronegative symmetrical synovitis with pitting edema. RS3PE syndrome. JAMA 1985;254:2763-7.

2. Olivieri I, Salvarani C, Cantini F. RS3PE syndrome: an overview. Clin Exp Rheumatol 2000;18(4 Suppl 20):S53-5.

3. Sekhon L. Remitting seronegative symmetrical synovitis with pitting edema. JAAPA 2010;23:38, 40, 43.

4. Russell EB. Remitting seronegative symmetrical synovitis with pitting edema syndrome: followup for neoplasia. J Rheumatol 2005;32:1760-1.

5. Ferrao C, Faria RM, Farrajota P, Vasconcelos C. Lucky to meet RS3PE. BMJ Case Rep 2013;7:2013.

6. Paksoy F, Ulaş $T$, Mazı EE, Damar AB, Borlu F. Syndrome of Remitting Seronegative Symmetrical Synovitis with Pitting Edema (RS3PE). Turk J Rheumatol 2010;25:88-90.

7. Arima K, Origuchi T, Tamai M, Iwanaga N, Izumi Y, Huang M, et al. RS3PE syndrome presenting as vascular endothelial growth factor associated disorder. Ann Rheum Dis 2005;64:1653-5.

8. Olive $A$, del Blanco J, Pons $M$, Vaquero $M$, Tena $X$. The clinical spectrum of remitting seronegative symmetrical synovitis with pitting edema. J Rheumatol 1997;24:333-6.

9. Cho E, Kim MH. Remitting seronegative symmetrical synovitis with pitting edema. Arch Dermatol 2012;10:1217-8.

10. Doğan KS, Tur BS, Tuncer S, Seckin B. Remitting Seronegative Symmetrical Synovitis with Pitting Edema (RS3PE): A Case Report. Rheumatism 2007;22:72-5.

11. Medrano San Ildefonso M, Mauri Llerda JA. Remitting seronegative symmetrical synovitis with pitting edema (RS3PE): a paraneoplastic syndrome? A new case. Clin Exp Rheumatol 2007;25:342.

12. Yalbuzdag SA, Sarıfakıoğlu $A B$, Karataş M. Unilateral RS3PE Syndrome. Turk J Rheumatol 2013;28:141-2.

13. Marto G, Klitna Z, Bileu MC, Barcelos A. Remitting seronegative symmetrical synovitis with pitting oedema syndrome, associated with prostate adenocarcinoma: a case report. Acta Reumatol Port 2010;35:358-60.

14. Mattace-Raso FU, van der Cammen TJ. Remitting seronegative symmetrical synovitis with pitting oedema associated with lung malignancy. Age Ageing 2007;36:470-1.

15. Russell EB. Remitting seronegative symmetrical synovitis with pitting edema syndrome: followup for neoplasia. J Rheumatol 2005;32:1760-1. 